Si te- dependent cont ri but i ons of P-gl ycopr ot ei $n$ and CYP3A to cycl osporin A absorption, and effect of dexamethasone in smal I int estine of mi ce

\begin{tabular}{|l|l|}
\hline 著者 & $\begin{array}{l}\text { Ji n I ngj i , Shi mada Tsut omu, Yokogawa Koi chi , } \\
\text { Nomur a Nasaaki, I shi zaki Junko, Pi ao Yi ngshi , } \\
\text { Kat o Yuki o, Tsuj i Aki ra, M yambt o Keni chi }\end{array}$ \\
\hline $\begin{array}{l}\text { j our nal or } \\
\text { publ i cat i on t i t l e }\end{array}$ & Bi ochemi cal Phar nacol ogy \\
\hline vol une & 72 \\
\hline number & 8 \\
\hline page range & $1042-1050$ \\
\hline year & $2006-10-01$ \\
\hline URL & ht t p: //hdl . handl e. net /2297/2958 \\
\hline
\end{tabular}




\title{
Site-dependent contributions of P-glycoprotein and CYP3A to cyclosporin A absorption, and effect of dexamethasone in small intestine of mice
}

\author{
Mingji Jin ${ }^{a}$, Tsutomu Shimada $^{a}$, Koichi Yokogawa ${ }^{a, b}$, Masaaki Nomura $^{a}$, Junko Ishizaki $^{a}$, \\ Yingshi Piao $^{c}$, Yukio Kato ${ }^{a}$, Akira Tsuji $^{a}$, Ken-Ichi Miyamoto ${ }^{a, b, *}$ \\ ${ }^{a}$ Graduate School of Natural Science and Technology, Kanazawa University, Kakuma, Kanazawa 920-1192, Japan \\ ${ }^{b}$ Department of Hospital Pharmacy, School of Medicine, Kanazawa University, 13-1 Takara-machi, Kanazawa 920-8641, Japan \\ ${ }^{\mathrm{c}}$ Department of Molecular Pharmacology, School of Medicine, Kanazawa University, 13-1 Takara-machi, Kanazawa 920-8640, Japan
}

\section{A R T I C L E I N F O}

Article history:

Received 10 May 2006

Accepted 21 July 2006

Keywords:

Cyclosporin A

Bioavailability

P-glycoprotein

Dexamethasone

CYP3A

In situ loop

mdr1a/1b knockout mice

\begin{abstract}
A B S T R A C T
We examined whether the oral bioavailability of cyclosporin A is controlled primarily by Pglycoprotein (P-gp) or CYP3A in the small intestine. In situ loop method was used to evaluate the uptake of cyclosporin A $(40 \mathrm{nmol})$ at the upper and lower intestine of wild-type and $m d r 1 a / 1 b$ knockout mice treated or not treated with dexamethasone $(75 \mathrm{mg} / \mathrm{kg} / \mathrm{day}, 7$ days, i.p.). Expression of CYP3A mRNA in the control group was higher in the upper than the lower intestine, while that of the multidrug resistance-1a (mdr1a) mRNA was in the opposite order. Dexamethasone administration potently induced CYP3A and mdr1a mRNAs in the lower and upper intestine, respectively. At $45 \mathrm{~min}$ after cyclosporin A administration into an upper intestinal loop of the control group of wild-type mice, the ratio of residual cyclosporin A to dose did not differ significantly from that of $m d r 1 a / 1 b$ knockout mice, whereas in dexamethasone-treated wild-type mice, the residual ratio was increased significantly. The ratio of the cyclosporin A metabolite M17 to cyclosporin A in portal venous blood at an upper intestinal loop of $m d r 1 a / 1 b$ knockout mice was much higher than that a lower intestinal loop. The M17/cyclosporin A ratio of portal venous blood at a lower intestinal loop in mdr1a/ $1 b$ knockout mice was increased significantly by dexamethasone treatment. These results suggest that, under physiological conditions, the oral bioavailability of cyclosporin A is mainly controlled by CYP3A in the upper intestine, rather than liver, but when P-gp is induced by steroid, the intestinal absorption of cyclosporin A may be inhibited.
\end{abstract}

C 2006 Published by Elsevier Inc.

\section{Introduction}

To determine appropriate dosage schedules of an immunosuppressant cyclosporin A for patients after transplantation, it is necessary to clarify the reason why the blood concentration of cyclosporin A is frequently unstable [1-3]. It is suggested that P-glycoprotein (P-gp) and/or CYP3A limit the oral bioavailability of digoxin, rifampin [4], vinblastine [5], dexamethasone tromethorphan [6], tacrolimus [7], sirolimus [8] and cyclosporin A $[9,10]$. Lown et al. [11] suggested that

\footnotetext{
* Corresponding author at: Department of Hospital Pharmacy, School of Medicine, Kanazawa University, 13-1 Takara-machi, Kanazawa 920-8641, Japan. Tel.: +81 76265 2045; fax: +81 762344280 .

E-mail address: miyaken@pharmacy.m.kanazawa-u.ac.jp (K.-I. Miyamoto). 0006-2952/\$ - see front matter (C) 2006 Published by Elsevier Inc.
} doi:10.1016/j.bcp.2006.07.020 
intestinal P-gp, rather than intestinal CYP3A, plays a key role in the interpatient variation in oral bioavailability of cyclosporin A. On the other hand, CYP3A accounts for about 30 and $70 \%$ of total CYP activity in the liver and small intestine, respectively [12-14], and intestinal first-pass metabolism mediated by CYP3A has been shown to be clinically relevant for several drugs, including cyclosporin A $[15,16]$. However, it remains to be fully clarified whether $\mathrm{P}$-gP and/or CYP3A controls the oral bioavailability of cyclosporin A by limiting absorption from the small intestine.

We have reported that the blood concentrations of cyclosporin A [17] and tacrolimus [18] were decreased by combined steroid hormones due to induction of P-gp and/or CYP3A in the liver and small intestine. Hsiu et al. [19] also suggested that quercetin significantly decreased the oral bioavailability of cyclosporin A by inducing P-gp and/or CYP3A4. Further, Konishi et al. [20] demonstrated that the oral bioavailability of cyclosporin $A$ is decreased by methylprednisolone, and the mechanism involves enhancement of small-intestinal P-gp function. Based on a study comparing the effects of high-dose dexamethasone $(75 \mathrm{mg} /$ $\mathrm{kg} /$ day intraperitoneally, for 7 days) in $m d r 1 a / 1 b$ knockout mice and wild-type mice, we concluded that P-gp plays only a small role in the absorption of cyclosporin A under physiological conditions, but after induction by dexamethasone, P-gp functions as an absorption barrier to cyclosporin $A$ in the small intestine [21]. In the present study, we used an in situ intestinal loop method to examine in detail the effects of both P-gp and CYP3A on the absorption of cyclosporin A from the upper and lower small intestine in wild-type and mdr1a/1b knockout mice treated with or without dexamethasone.

\section{Materials and methods}

\subsection{Materials}

Sandimmun ${ }^{\circledR}$ injection (cyclosporin A) and dexamethasone were purchased from Novartis Pharma Co. Ltd. (Tokyo, Japan) and Wako Pure Chemical Industries (Osaka, Japan), respectively. A cyclosporin A metabolite (M17), was supplied by Shiseido Co. Ltd. (Tokyo, Japan). Other reagents were purchased from Sigma Co. (St. Louis, MO).

\subsection{Animal preparation}

All animal experiments were performed in accordance with the guidelines of the Institutional Animal Care and Use Committee of Kanazawa University. Experiments were performed on male mdr1a/1b knockout mice (body weight 22-27 g, Taconic Farms Inc., NY, USA). We used male FVB/ NJcl mice (body weight 23-26 g, SLC, Hamamatsu, Japan) as the control wild-type mice. Mice were intraperitoneally injected daily for 7 days with a corn oil solution of dexamethasone $(75 \mathrm{mg} / \mathrm{kg} /$ day $)$. The control mice were intraperitoneally injected daily for 7 days with corn oil alone. Mice were fasted for $12 \mathrm{~h}$ prior to administration of cyclosporin A into a small intestinal loop, but water was freely available.

\subsection{In situ absorption experiments}

The in situ closed loop experiments were performed according to Bronner and Yost [22]. Following anesthetization of mice by intraperitoneal injection of sodium pentobarbital $(50 \mathrm{mg} / \mathrm{kg}$, Sigma Co.), the abdomen was opened by a midline longitudinal incision and a $5 \mathrm{~cm}$ upper (duodenum, jejunum) or lower (ileum) segment was isolated on a thermostatically controlled board at $37{ }^{\circ} \mathrm{C}$. For the upper segment, we used $5 \mathrm{~cm}$ of upper small intestine from the pylorus, because the duodenum of mouse is short. The segment was rinsed with MES buffer $(5 \mathrm{mM} \mathrm{KCl}, 100 \mathrm{mM} \mathrm{NaCl}, 10 \mathrm{mM} \mathrm{MES}, 85 \mathrm{mM}$ mannitol, $0.01 \%$ polyethylene glycol; pH 6.4) warmed to $37^{\circ} \mathrm{C}$. A $0.4 \mathrm{~mL}$ aliquot of MES buffer containing cyclosporin A $(40 \mathrm{nmol})$ was injected into the closed loop at $1.5 \mathrm{~h}$ after the last administration of dexamethasone. Blood samples (100$500 \mu \mathrm{L}$ ) were collected from the jugular vein and the portal vein at $45 \mathrm{~min}$ after in situ loop administration [23]. The small intestine was quickly excised, rinsed well with ice-cold saline, blotted dry and weighed, then homogenized in icecold saline $(10 \%, \mathrm{w} / \mathrm{v})$. In this study, the initial dose $(40 \mathrm{nmol})$ of cyclosporin A administered into the closed loop was corrected for adsorption, which was determined by measuring the amount of cyclosporin A in the loop immediately after in situ administration, because cyclosporin A is readily adsorbed on the small intestinal membrane. The ratio of adsorption to dose was $0.203 \pm 0.018$ of dose (mean \pm S.D., $n=15)$.

\subsection{Measurement of apparent tissue-to-blood concentration ratio of M17}

mdr1a/1b knockout mice were intravenously or orally administered with cyclosporin A $(10 \mathrm{mg} / \mathrm{kg})$. Blood samples were collected at $45 \mathrm{~min}$ after the administration from the jugular vein under light ether anesthesia and stored at $-30^{\circ} \mathrm{C}$ until assay. Mice were killed by decapitation, then the intestine and liver were quickly excised, rinsed well with ice-cold saline, blotted dry, and weighed.

\subsection{Preparation of microsomes and plasma membrane fraction}

For preparation of microsomes, the liver was homogenized in three volumes of $100 \mathrm{mM}$ Tris-HCl buffer (100 mM KCl, $1 \mathrm{mM}$ EDTA, pH 7.4). Microsomes were prepared as reported previously [24] and stored at $-80^{\circ} \mathrm{C}$ until use. The small intestine was quickly removed and washed with buffer containing $2 \mathrm{mM} \mathrm{HEPES}, 0.9 \% \mathrm{NaCl}$ and $0.5 \mathrm{mM}$ phenylmethylsulfonyl fluoride (PMSF). Mucosa was scraped off with a slide glass on ice and homogenized in a buffer containing $300 \mathrm{mM}$ mannitol, 5 mM EDTA, 5 mM HEPES and 1 mM PMSF (pH 7.1). The homogenate was centrifuged at $10,000 \times g$ for $20 \mathrm{~min}$, and the supernatant was centrifuged at $105,000 \times \mathrm{g}$ for $60 \mathrm{~min}$ at $4{ }^{\circ} \mathrm{C}$. The pellet was added to the buffer containing $500 \mathrm{mM}$ $\mathrm{KCl}, 1 \mathrm{mM}$ EDTA, $2 \mathrm{mM}$ dithiothreithol (DTT) and $50 \mathrm{mM}$ potassium phosphate buffer (KPB, pH 7.4) and again centrifuged at $105,000 \times \mathrm{g}$ for $60 \mathrm{~min}$ at $4{ }^{\circ} \mathrm{C}$. The pellet was added to the buffer containing $1 \mathrm{mM}$ EDTA, $2 \mathrm{mM}$ DTT and $50 \mathrm{mM} \mathrm{KPB}$ (pH 7.4), then stored at $-80^{\circ} \mathrm{C}$ until use.
80

81

82

83

84

85

86

87

88

89

90

91

92

93

94

95

96

97

98

99

100

101

102

103

104 
For the preparation of plasma membrane, the liver was homogenized in $10 \mathrm{mM}$ Tris- $\mathrm{HCl}$ buffer ( $\mathrm{pH}$ 7.5) containing $2 \mathrm{mM} \mathrm{CaCl}_{2}$ at $4{ }^{\circ} \mathrm{C}$. The homogenate was centrifuged at $3500 \times g$ for $10 \mathrm{~min}$, and the supernatant was then centrifuged at $15,000 \times g$ for $30 \mathrm{~min}$. The pellet was washed, resuspended in $50 \mathrm{mM}$ Tris- $\mathrm{HCl}$ buffer ( $\mathrm{pH} \mathrm{7.2),} \mathrm{and} \mathrm{twice}$ centrifuged at $10,000 \times g$ for $5 \mathrm{~min}$, then stored at $-80^{\circ} \mathrm{C}$ until use. The small intestine was quickly removed and washed with ice-cold isotonic saline containing $1 \mathrm{mM}$ PMSF. Mucosa was scraped off with a slide glass on ice and homogenized in a buffer containing $250 \mathrm{mM}$ sucrose, $50 \mathrm{mM}$ Tris-HCl ( $\mathrm{pH}$ 7.4), and $1 \mathrm{mM}$ PMSF. The homogenate was centrifuged at $3000 \times g$ for $10 \mathrm{~min}$, and the supernatant was again centrifuged at $15,000 \times \mathrm{g}$ for $30 \mathrm{~min}$. The pellet was resuspended in $0.5 \mathrm{~mL}$ of a buffer containing $50 \mathrm{mM}$ mannitol, $50 \mathrm{mM}$ Tris- $\mathrm{HCl}$ ( $\mathrm{pH}$ 7.4), and $1 \mathrm{mM}$ PMSF, and stored at $-80^{\circ} \mathrm{C}$ until use. Protein contents were measured according to the method of Lowry et al. [25].

\subsection{Measurement of metabolic activity of CYP3A}

The microsomal activity of CYP3A was measured in terms of conversion of cyclosporin A to M17, essentially according to Arlotto et al. [26]. The reaction solution $(180 \mu \mathrm{L})$ contained cyclosporin A (final concentration 1-50 $\mu \mathrm{M}$ ) and microsomal protein (final concentration $1 \mathrm{mg} / \mathrm{mL}$ ) in $100 \mathrm{mM}$ phosphate buffer ( $\mathrm{pH}$ 7.4). It was pre-incubated at $37^{\circ} \mathrm{C}$ for $2 \mathrm{~min}$, then $20 \mu \mathrm{L}$ of the reaction buffer $\left(5 \mathrm{mM} \mathrm{NADP}^{+}, 50 \mathrm{mM}\right.$ glucose-6-phosphate, $50 \mathrm{mM} \mathrm{MgCl}_{2}$, and $10 \mathrm{U} / \mathrm{mL}$ glucose-6phosphate dehydrogenase) was added. The whole was incubated for $5 \mathrm{~min}, 100 \mu \mathrm{L}$ of cold acetonitrile in ice bath was added, and M17 was measured using highperformance liquid chromatograpy (HPLC), as described below.

\subsection{Assay of cyclosporin A and its metabolite M17}

The assay for cyclosporin A and its metabolite M17 was performed according to Khoschsorur et al. [27]. Briefly, a sample of blood or tissue, $1 \mathrm{~mL}$ of $0.18 \mathrm{~N} \mathrm{HCl}$ and $4 \mathrm{~mL}$ of diethyl ether were added to a glass tube, but an internal standard was not used. The tube was shaken vigorously for $5 \mathrm{~min}$. After centrifugation for $5 \mathrm{~min}$ at $3000 \times \mathrm{g}$, the ether layer was collected in another glass tube containing $1.25 \mathrm{~mL}$ of $0.1 \mathrm{~N} \mathrm{NaOH}$. After shaking and centrifugation, the ether layer was evaporated for $30 \mathrm{~min}$ at room temperature. The residue was reconstituted with $300 \mu \mathrm{L}$ of mobile phase and a $100 \mu \mathrm{L}$ aliquot was injected into the HPLC system (LC-9A, Shimadzu Co. Ltd., Kyoto, Japan). All samples were analyzed on an HPLC system equipped with a Waters Spherisorb $5 \mu \mathrm{m}$ CN column ( $250 \mathrm{~mm} \times 4.6 \mathrm{~mm}$ i.d., Waters Co. Ltd., MA). The absorbance was detected at a wavelength of $210 \mathrm{~nm}$. The mobile phase consisted of acetonitrile:water (33:67) and was pumped at a rate of $1.2 \mathrm{~mL} / \mathrm{min}$. The limit of quantification for cyclosporin A and M17 was 30 and $5 \mathrm{ng} / \mathrm{mL}$ in $300 \mu \mathrm{L}$ of plasma, respectively, and these calibration curves were good linear $(r>0.98)$. These coefficients of the variation in the within-run $(n=5)$ and the between-run (5 days) precisions were below $5 \%$.
2.8. Reverse transcription-polymerase chain reaction (RTPCR) assay

Total RNA was isolated from the liver and small intestine by using an Isogen Kit (Wako). Synthesis of cDNA from the isolated total RNA was carried out using RNase H-reverse transcriptase (GIBCO BRL, Rockville, MD). Reverse transcription $(\mathrm{RT}$ ) reactions were carried out in $40 \mathrm{mM} \mathrm{KCl}, 50 \mathrm{mM}$ Tris$\mathrm{HCl}$ ( $\mathrm{pH}$ 8.3), $6 \mathrm{mM} \mathrm{MgCl}_{2}, 1 \mathrm{mM} \mathrm{DTT}, 1 \mathrm{mM}$ each of dATP, dCTP, dGTP, and dTTP, 10 units of RNase inhibitor (Promega, Madison, WI), $100 \mathrm{pmol}$ of random hexamer, total RNA and 200 units of the Moloney murine leukemia virus reverse transcriptase (Gibco-BRL, Berlin, Germany) in a final volume of $50 \mu \mathrm{L}$ at $37^{\circ} \mathrm{C}$ for $120 \mathrm{~min}$. Polymerase chain reaction (PCR) was carried out in a final volume of $20 \mu \mathrm{L}$, containing $1 \mu \mathrm{L}$ of $\mathrm{RT}$ reaction mixture, $50 \mathrm{mM} \mathrm{KCl,} 20 \mathrm{mM}$ Tris- $\mathrm{HCl}$ ( $\mathrm{pH} 8.3$ ), $2.5 \mathrm{mM} \mathrm{MgCl}_{2}, 0.2 \mathrm{mM}$ each of dATP, dCTP, dGTP, and dTTP, $1 \mu \mathrm{M}$ each of the mixed oligonucleotide primers, and 1 unit of Taq DNA polymerase (Gibco-BRL). Reported primers were used for mouse mdr1a (576 bp) [28], mouse mdr1b (486 bp) [29], mouse CYP3A (670 bp) [29], and mouse $\beta$-actin (456 bp) [30]. Each cycle consisted of $45 \mathrm{~s}$ at $94^{\circ} \mathrm{C}, 60 \mathrm{~s}$ at $60^{\circ} \mathrm{C}$, and $75 \mathrm{~s}$ at $72{ }^{\circ} \mathrm{C}$ for mdr $1 a$ and $m d r 1 b, 45 \mathrm{~s}$ at $94^{\circ} \mathrm{C}, 60 \mathrm{~s}$ at $56^{\circ} \mathrm{C}$, and $75 \mathrm{~s}$ at $72{ }^{\circ} \mathrm{C}$ for $\mathrm{CYP} 3 \mathrm{~A}$, and $45 \mathrm{~s}$ at $94{ }^{\circ} \mathrm{C}, 60 \mathrm{~s}$ at $58^{\circ} \mathrm{C}$, and $75 \mathrm{~s}$ at $72{ }^{\circ} \mathrm{C}$ for $\beta$-actin. The PCR reaction was run for 22 cycles for $m d r 1 a$ and $\beta$-actin, for 26 cycles for $m d r 1 b$, and for 38 cycles for CYP3A.

\subsection{SDS-PAGE and immunoblotting}

SDS-PAGE and immunoblotting with peroxidase/antiperoxidase staining of the plasma membrane for P-gp and of the microsomes for CYP3A were carried out essentially as described by Laemmli [31] and Guengerich et al. [32]. The amounts of sample protein of liver and small intestine were 4 and $200 \mu \mathrm{g}$ for CYP3A or 30 and $300 \mu \mathrm{g}$ for P-gp, respectively. The sample protein was electrophoresed on $10 \%$ sodium dodecyl sulfate-polyacrylamide gel and transferred onto PVDF membrane filters (Millipore Co., Billerica, MA). After having been blocked with $5 \%$ skim milk, the filters were incubated overnight at $4{ }^{\circ} \mathrm{C}$ with primary antibody, mouse anti-P-gp C219 (Dako Co., Carpinteria, CA) and rabbit anti-rat CYP3A2 antibody (Daiichi Pure Chemicals Co. Ltd., Tokyo, Japan), and for $1 \mathrm{~h}$ with secondary antibody, anti-mouse IgG HRP-linked antibody (Cell Signaling, Beverly, MA) and mouse anti-rabbit IgG-HRP (Santa Cruz Bio., Santa Cruz, CA). Thereafter, the sample was extensively washed with phosphate-buffered saline. The immunopositive band was detected by means of a light-emitting nonradioactive detection system (Amersham International plc, Little Chalfont, Buckinghamshire, UK) with Kodak X-Omat R film (Eastman Kodak Co., Rochester, NY).

\subsection{Data analysis}

The data were analyzed using Student's t-test to compare the unpaired mean values of two sets of data. The number of determinations is noted in each table and figure. A value of $P<0.05$ or 0.01 was taken to indicate a significant difference between sets of data. The electrophoresis results were analyzed by using NIH Image software.
192 

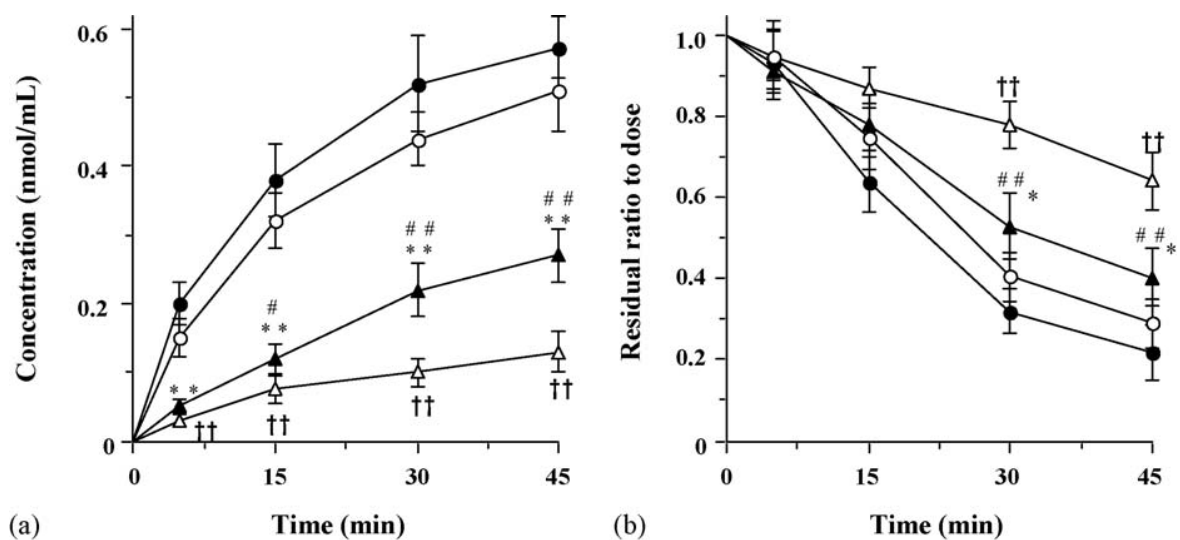

Fig. 1 - ( $a$ and b) Time courses of jugular venous blood concentration (a) and values of the ratio of residual cyclosporin $A$ to dose (b) after in situ administration of cyclosporin A $(40 \mathrm{nmol})$ into a loop of wild-type mouse upper $(\bigcirc)$ or lower $(\triangle)$ intestine or $m d r 1 a / 1 b$ knockout mouse upper $(0)$ or lower $(\Delta)$ intestine. Each point and bar represent the mean \pm S.D. of four mice. Significantly different from the wild-type mouse upper intestine at ${ }^{\dagger} P<0.05$ and ${ }^{\dagger \dagger} P<0.01$, respectively. Significantly different from the $m d r 1 a / 1 b$ knockout mouse upper intestine at ${ }^{*} \mathrm{P}<0.05$ and ${ }^{* *} \mathrm{P}<0.01$, respectively. Significantly different from the wild-type mouse lower intestine at ${ }^{\#} P<0.05$ and ${ }^{\# \#} P<0.01$, respectively. (a) CyA in jugular venous blood and (b) CyA in intestinal loop.

\section{Results}

3.1. Site-dependent absorption of cyclosporin A from intestinal loop after an in situ administration

Fig. 1a shows the time courses of jugular venous blood concentration of cyclosporin A after administration of cyclosporin A (40 nmol) into upper and lower intestinal loops of wild-type and mdr1a/1b knockout mice. When cyclosporin A was administered into the upper intestine, its concentration rapidly increased without any significant difference between the two types of mice. In contrast, after administration of cyclosporin A into the lower intestine, the blood cyclosporin A concentration was significantly lower than that after administration into the upper intestine; moreover, the cyclosporin A concentration was significantly higher in mdr1a/1b knockout mice than in wild-type mice. As shown in Fig. $1 b$, the residual amount of cyclosporin $A$ in the intestinal loop was essentially a mirror image of the change in the blood concentration, indicating that the absorption of cyclosporin A was higher in the upper intestine than in the lower intestine in both types of mice, and that the absorption from the lower intestine was higher in mdr1a/ $1 b$ knockout mice than in wild-type mice.

3.2. Effect of dexamethasone on absorption of cyclosporin A and its metabolite M17 from intestinal loop after an in situ administration

Fig. 2 shows the concentrations of cyclosporin A (a) and its major metabolite M17 (b) in portal venous blood and the ratio of residual cyclosporin A to dose (c) in upper and lower
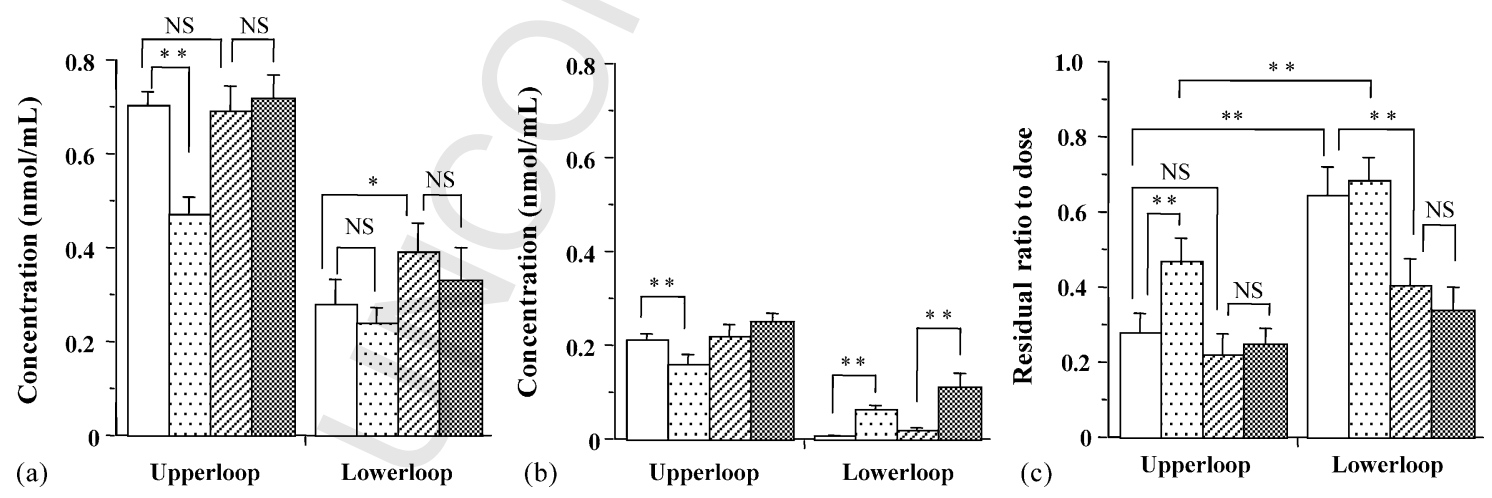

Fig. 2 - The concentrations of cyclosporin A (a) and M17 (b) in portal venous blood and the ratio of residual cyclosporin A to dose (c) in an upper or lower intestinal loop at $45 \mathrm{~min}$ after in situ administration of cyclosporin A (40 $\mathrm{nmol}$ ) into an upper or lower intestinal loop of wild-type or mdr1a/1b knockout mice with or dexamethasone treatment (75 mg/kg, daily, 7 times), at $1.5 \mathrm{~h}$ after the last administration. Each column and bar represent the mean \pm S.D. of four mice. Significantly different at ${ }^{*} \mathrm{P}<0.05$ and ${ }^{* *} \mathrm{P}<0.01$, respectively. (NS) no significant difference. ( $\square$ ) Wild-type without dexamethasone treatment; (目)

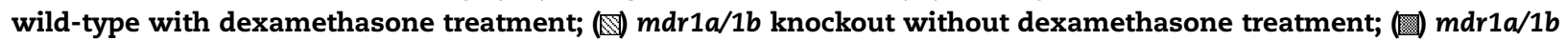
knockout with dexamethasone treatment. 
intestinal loops at $45 \mathrm{~min}$ after in situ administration of cyclosporin A (40 nmol) in wild-type and $m d r 1 a / 1 b$ knockout mice treated with or without dexamethasone.

There was no significant difference in the portal venous blood concentrations of cyclosporin A after administration into the upper intestinal loop between the untreated control groups of both types of mice, but the concentration after administration into the lower intestinal loop of $m d r 1 a / 1 b$ knockout mice was significantly higher than that in the case of wild-type mice. These findings were consistent with the data on jugular venous blood concentration of cyclosporin A after administration of cyclosporin A into the intestinal loops (Fig. 1a).

In mice treated with dexamethasone, the blood concentration of cyclosporin A after administration into the upper intestinal loop was significantly decreased in wild-type mice, but was not changed in mdr1a/1b knockout mice. When cyclosporin A was administered into the lower loop, its blood concentration was not significantly decreased by dexamethasone treatment in both types of mice (Fig. 2a). Fig. 2c shows the ratio of residual cyclosporin $A$ to the dose in upper and lower intestinal loops after administration of cyclosporin A. The dexamethasone treatment significantly increased the residual ratio of cyclosporin A in the upper intestinal loop of wild-type mice, but not mdr1a/1b knockout mice. Thus, it appears that dexamethasone inhibited cyclosporin A absorption from the upper intestine of wild-type mice, but not P-gp-deficient mice.

As regards the metabolite, the portal venous blood concentrations of M17 after administration of cyclosporin A into the upper intestinal loop were similar in both types of mice; however, dexamethasone treatment significantly decreased the M17 concentration in wild-type mice, but not the knockout mice. In the case of administration into the lower intestinal loop, the blood concentrations of M17 in both types of mice were very much lower than those after administration into the upper intestinal loop, and were significantly increased by dexamethasone treatment (Fig. 2b).

Fig. 3 shows the values of the concentration ratio of M17 to cyclosporin A in jugular and portal venous blood at $45 \mathrm{~min}$ after administration of cyclosporin A (40 nmol) into the small intestine loop in $m d r 1 a / 1 b$ knockout mice treated with or without dexamethasone. After administration into the upper intestinal loop, there was no significant difference between the values of the $\mathrm{M} 17 /$ cyclosporin A ratio in the untreated control group and the dexamethasone group, and in jugular blood and portal blood. However, after administration into the lower intestinal loop, the value of the M17/cyclosporin A ratio of the dexamethasone group was about seven times larger than that in the untreated control group in both jugular and portal blood. The M17/cyclosporin A ratios in portal blood were significantly higher than those in jugular blood in both groups.

3.3. Apparent tissue-to-blood concentration ratio of M17 in small intestine and liver after intravenous or oral administration of cyclosporin A

Fig. 4 shows the values of the apparent tissue-to-blood concentration ratio ( $\left.K_{b, a p p}\right)$ of $M 17$ for the upper small intestine, lower small intestine and liver of $m d r 1 a / 1 b$ knockout mice at $45 \mathrm{~min}$ after an intravenous or oral administration of cyclosporin A $(10 \mathrm{mg} / \mathrm{kg})$.

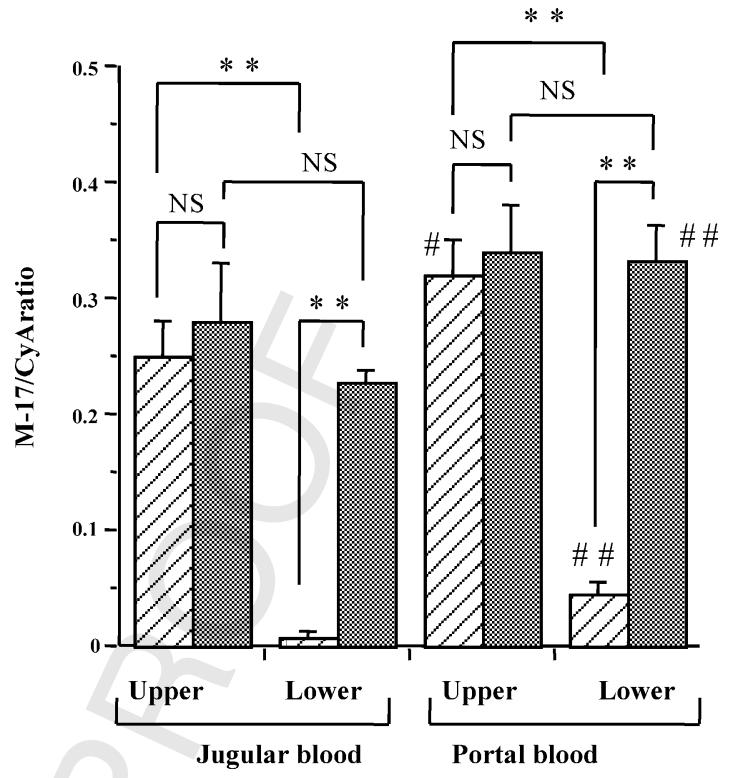

Fig. 3 - The value of the M17/cyclosporin A ratio in jugular or portal venous blood at $\mathbf{4 5} \mathrm{min}$ after in situ administration of cyclosporin $A(40 \mathrm{nmol})$ into the upper or lower intestinal loop of $m d r 1 a / 1 b$ knockout mice with (回) or without (圆) dexamethasone treatment $(75 \mathrm{mg} / \mathrm{kg}$, daily, 7 times), at $1.5 \mathrm{~h}$ after the last administration. Each column and bar represent the mean \pm S.D. of four mice.

Significantly different from the each group of jugular venous blood at ${ }^{\#} P<0.05$ and ${ }^{\# \#} P<0.01$, respectively.

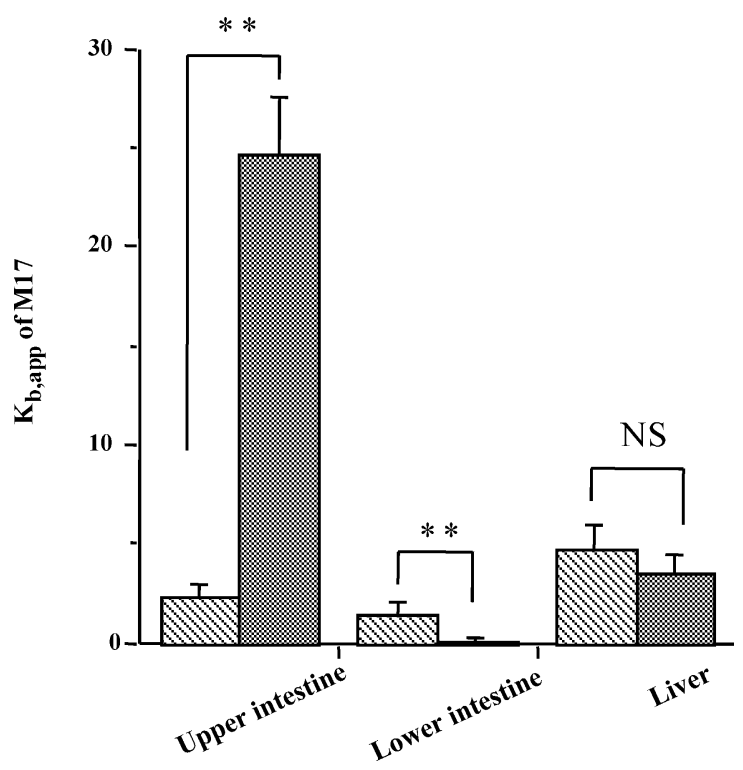

Fig. 4 - The values of the apparent tissue-to-blood concentration ratio $\left(K_{b \text {,app }}\right)$ of M17 in the upper intestine, lower intestine and liver at $45 \mathrm{~min}$ after i.v. (四) or p.o. (回) administration of cyclosporin $A(10 \mathrm{mg} / \mathrm{kg})$ in $\mathrm{mdr} 1 \mathrm{a} / 1 \mathrm{~b}$ knockout mice. Each column and bar represent the mean \pm S.D. of four mice. ** Significantly different from i.v. administration at $P<0.01$. 
There was no difference between the $K_{b \text {,app }}$ values of M17 for the upper and lower intestine after intravenous administration, but the $K_{\mathrm{b} \text {,app }}$ value for the upper intestine after oral administration was very much higher than that after intravenous administration, while that for the lower intestine was very much lower. There was no difference between the $K_{b, a p p}$ values for the liver after intravenous and oral administrations, but the value after intravenous administration was about two to three times higher than those of the two regions of small intestine. The tissue concentration of unchanged cyclosporin A was not evaluated, because of the high tissue adsorption of the drug in the small intestine after oral administration.

\subsection{Expression of P-gp and CYP3A in small intestine and} liver

Fig. 5 shows the results of quantitation of RT-PCR mdr1a, $m d r 1 b$ and CYP3A mRNAs in the upper and lower intestine and liver in wild-type and $m d r 1 a / 1 b$ knockout mice treated with or without dexamethasone. In the untreated wild-type group, the expression of mdr1a mRNA was less in the upper intestine than in the lower intestine, while that of $m d r 1 b$ mRNA was in the opposite relationship. But, the expression levels of $m d r 1 b$
mRNA in the lower intestine and the liver of wild-type mice were much lower than those of mdria mRNA, and the influence of dexamethasone treatment on the expression of $m d r 1 b$ mRNA could not be observed clearly. Treatment with dexamethasone clearly altered the expression of mdr1a mRNA in the upper intestine. The expression of CYP3A mRNA in the untreated group of wild-type and knockout mice was higher in the upper intestine than in the lower intestine. Dexamethasone induced CYP3A mRNA expression more strongly in the lower intestine than in the upper intestine. Dexamethasone also induced mdrla and CYP3A mRNA expression in the liver. The expression levels of P-gp and CYP3A proteins and the effect of dexamethasone were confirmed by Western blot analysis using tissues of wildtype mice (Fig. 6). The protein levels of P-gp in the upper intestine and liver were elevated to about four and three times the untreated control level by dexamethasone treatment, respectively, but the level in the lower intestine was hardly changed by dexamethasone. On the other hand, the protein levels of CYP3A in the lower intestine and liver were elevated to about five and two times the control level by dexamethasone treatment, respectively, while the level in the upper intestine was little elevated.
Wild-type mice mdr1a

mdrlb

CYP3A

$\beta$-actin

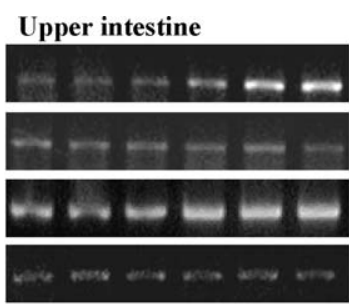

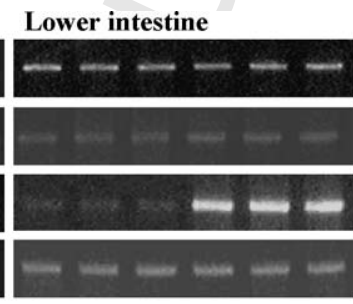

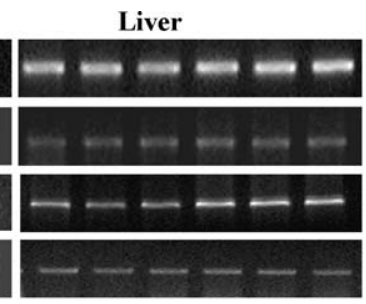

mdr1a/1b Knockout mice

CYP3A

$\beta$-actin
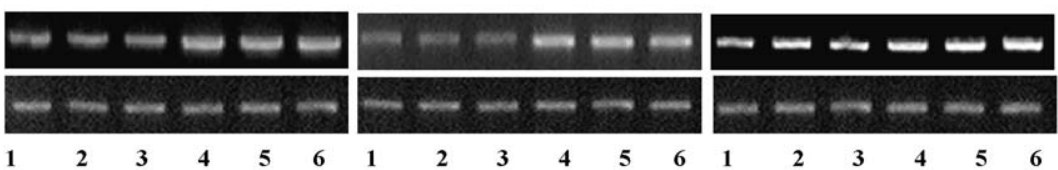

(a)
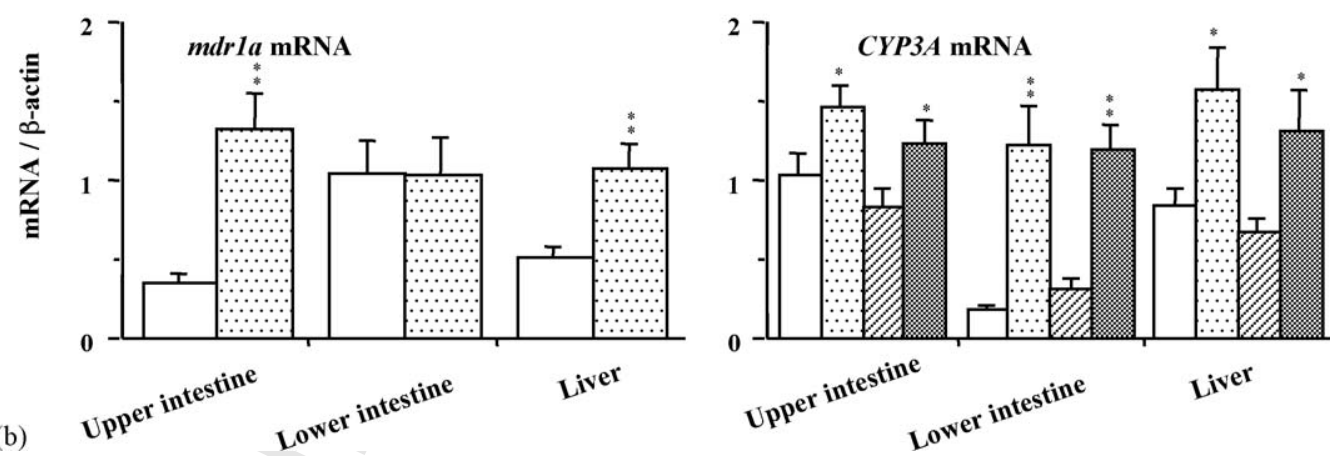

Fig. 5 - ( $a$ and $b$ ) Effects of dexamethasone on the expression of $m d r 1 a, m d r 1 b$ and CYP3A mRNAs in upper intestine, lower intestine and liver of wild-type and $m d r 1 a / 1 b$ knockout mice with or without dexamethasone treatment, at $1.5 \mathrm{~h}$ after the last dexamethasone treatment. (a) Mice were given successive i.p. administrations of dexamethasone (75 mg/kg, daily, 7 times). The sizes of the reverse transcriptase-polymerase chain reaction (RT-PCR) products are $576 \mathrm{bp}$ (mdr1a), $486 \mathrm{bp}$ (mdr1b), and 670 bp (CYP3A). Lanes 1-3: no treatment; lanes 4-6: dexamethasone treatment. (b) Relative expression of mdr1a and CYP3A mRNAs of wild-type and $m d r 1 a / 1 b$ knockout mice with or without dexamethasone treatment. Each column and bar represent the mean \pm S.D. of three mice. Significantly different from the dexamethasone-untreated mice at $P<0.05$ and ${ }^{* *} P<0.01$, respectively. ( $\square$ ) Wild-type without dexamethasone treatment; (圆) wild-type with dexamethasone treatment; (图) $m d r 1 a / 1 b$ knockout without dexamethasone treatment; (而 mdr1a/1b knockout with dexamethasone treatment. 
(a)

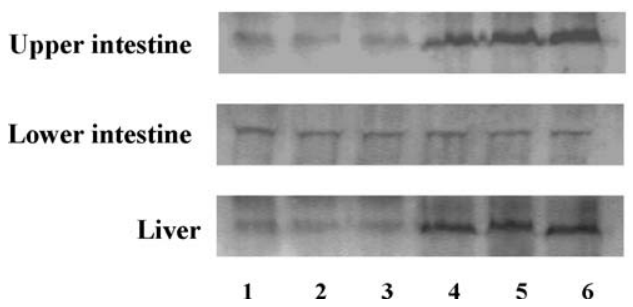

(b)

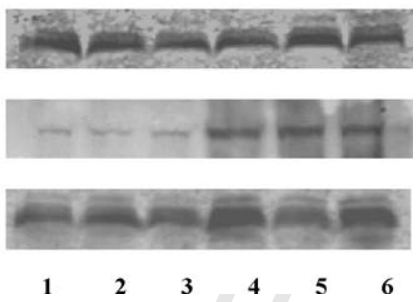

Fig. 6 - Western blot analysis of P-gp (a) and CYP3A (b) proteins in the upper intestine, lower intestine and liver of wild-type mice with or without dexamethasone treatment, at $1.5 \mathrm{~h}$ after the last dexamethasone treatment. Mice were given successive i.p. administrations of dexamethasone $(75 \mathrm{mg} / \mathrm{kg}$, daily, 7 times). Lanes 1-3: no treatment; lanes 4-6: dexamethasone treatment.

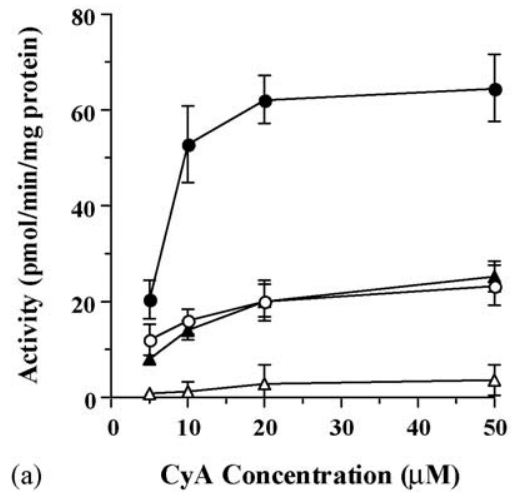

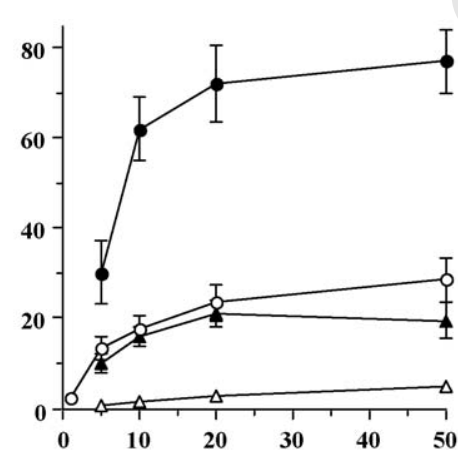

(b) CyA Concentration $(\mu \mathrm{M})$

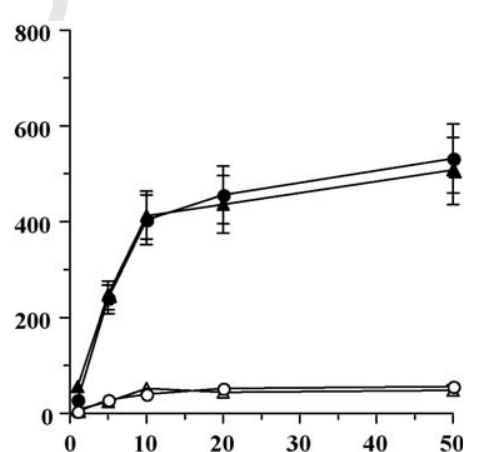

(c) $\mathrm{CyA}$ Concentration $(\mu \mathrm{M})$

Fig. 7 - (a-c) Enzyme activity of microsomal formation of M17 from cyclosporin A. Microsomes were obtained from isolated small intestine of wild-type mice (a), small intestine of $m d r 1 a / 1 b$ knockout mice (b) and liver (c) of wild-type and mdr1a/1b knockout mice with (closed symbol) or without (open symbol) dexamethasone treatment (75 mg/kg, daily, 7 times), at $1.5 \mathrm{~h}$ after the last administration. Each symbol represents the mean \pm S.D. of four mice. (a and b) $(\bigcirc)$ Upper intestine; $(\triangle)$ lower intestine; (c) $(\bigcirc)$ wild-type mice; $(\triangle)$ mdr1a/1b knockout mice.

\subsection{Enzyme activity of CYP3A in small intestine and liver}

Fig. 7 shows the activity for in vitro formation of M17 from cyclosporin A in microsome preparations from the small intestine and liver of wild-type and $m d r 1 a / 1 b$ knockout mice treated with or without dexamethasone. There was little difference in the activity of the small intestine or liver between untreated wild-type and $\operatorname{mdr} 1 a / 1 b$ knockout mice. However, the activities in the upper intestine of both types of mice were much higher than those in the lower intestine. Further, the activities in the liver of both types of untreated mice were about 20 times higher than those in the upper intestine. Dexamethasone treatment increased the activities in the upper intestine and liver of both types of mice by about 3- and 25-fold, respectively. Further, dexamethasone treatment increased the activities in the lower intestine, which almost lacked metabolic activity in untreated mice, to the levels seen in the upper intestine of untreated mice.

\section{Discussion}

We previously suggested that P-gp had little influence on the intestinal absorption of cyclosporin A under physiological conditions, whereas after induction by dexamethasone, it markedly inhibited the oral bioavailability in mice; however, the contribution of CYP3A to the intestinal absorption was not evaluated [21]. In that study, we found that the magnitude of mdr1a mRNA was in the order of ileum $>$ jejunum $>$ duodenum, while that of CYP3A mRNA was in the opposite order; further, of cyclosporin A under physiological conditions, whereas after induction by dexamethasone induced these mRNAs more strongly in the intestinal regions where expression was weaker in untreated animals. Thorn et al. [33] reported regarding the expression of CYP and $m d r$ mRNAs along the human gastrointestinal tract. Then, the pattern of expression of these mRNAs in duodenum, jejunum and ileum of human was well similar to those of our mice.

In the present study, in order to clarify the intestinal sitespecific roles and functions of $\mathrm{P}$-gp and the cyclosporin Ametabolizing enzyme CYP3A in cyclosporin A absorption, we firstly confirmed that the expression of P-gP and CYP3A at the mRNA and protein levels in the upper and lower small intestine is fundamentally the same as the above-described results (Figs. 5 and 6).

Yamaguchi et al. reported that the intestinal secretion of grepafloxacin in mdr1a/1b knockout mice is decreased to $62 \%$ of that in wild-type mice, and pre-administration of cyclosporin A to wild-type mice resulted in comparable secretion to that in $m d r 1 a / 1 b$ knockout mice with or without cyclosporin A 
pre-administration [34]. The ratio of intestinal secretion to dose of grepafloxacin in both types of mice was in the range of $5-7 \%$. Similarly, we found that the values of the ratio of intestinal secretion of cyclosporin A to dose over $45 \mathrm{~min}$ after an i.v. administration of cyclosporin A (10 mg/kg) in wild-type and $m d r 1 a / 1 b$ knockout mice were $0.8 \pm 0.2$ and $0.6 \pm 0.2 \%$ (mean \pm S.D., $n=4$ ), respectively. Therefore, we considered that the intestinal secretion of cyclosporin A is negligible in the context of this intestinal loop study.

We have shown here that (1) the absorption of cyclosporin A from the upper intestine is very much higher than that from the lower intestine; (2) in the upper intestine, there is no significant difference in absorption of cyclosporin A between wild-type and mdr1a/1b knockout mice, whereas in the lower intestine, absorption of cyclosporin A in $m d r 1 a / 1 b$ knockout mice was higher than that of wild-type mice; (3) dexamethasone treatment inhibited the absorption of cyclosporin A from the upper intestine, but not from the lower intestine, in wildtype mice; (4) the blood concentration of the major metabolite M17 was higher after administration of cyclosporin A into the upper intestine than into the lower intestine and (5) the blood concentration of M17 was lowered by dexamethasone after administration of cyclosporin $\mathrm{A}$ into the upper intestine in wild-type mice, but not $m d r 1 a / 1 b$ knockout mice, whereas it was increased by dexamethasone after administration of cyclosporin A into the lower intestine in both types of mice (Figs. 1 and 2). Furthermore, P-gp was expressed more strongly in the lower intestine than in the upper intestine at both the mRNA and protein levels, and the protein level in the upper intestine was strongly induced by cyclosporin A under physiological conditions, whereas after induction by dexamethasone. In contrast, CYP3A was expressed more strongly in the upper intestine than in the lower intestine in terms of both protein level and metabolic activity, and it was more strongly induced by dexamethasone in the lower intestine than in the upper intestine. These findings represent a significant extension of our previous study [21], and we confirmed that cyclosporin A was absorbed predominantly from the upper intestine in mice, as reported by Cakaloglu et al. [35].

It is well known that the major metabolite of cyclosporin A is M17, rather than M1 or M21, which are generated by CYP3A in intestinal or hepatic microsomes [36,37]. Cyclosporin A may be metabolized to M17 during transport in mucosal epithelial cells of upper intestine (Figs. 2 and 4). Although the cyclosporin Ametabolizing activity in the upper intestine is only about onethird of that in the liver, the activity is increased to the level in the liver by dexamethasone treatment(Fig. 7). After dexamethasone treatment, the formation of M17 was significantly increased in the lower intestine (Fig. 2c). Moreover, it is suggested that cyclosporin A is extensively metabolized to M17 in the small intestine rather than in the liver after oral administration of cyclosporin A, since the ratio of M17/cyclosporin A was higher in portal blood than in jugular blood, irrespective of dexamethasone treatment and administration route (Fig. 3). We consider that cyclosporin A undergoes a first-pass effect from CYP3A in the upper intestine, rather than in the liver.

mdr1a/1b knockout mice have similar CYP3A activity, but are deficient in P-gp, compared with the wild-type mice. Schuetz et al. [38] has been reported that CYP3A catalytic activity measured as midazolam $1^{\prime}$ - and 4-hydroxylation in liver microsomes from these knockout mice revealed a rank order of activities with $\operatorname{mdr} 1 \mathrm{a} / 1 \mathrm{~b}(-/-)>\operatorname{mdr} 1 \mathrm{a}(-/-)>$ mdr1b $(-/-)>\operatorname{mdr} 1 \mathrm{a} / 1 \mathrm{~b}(+/+)$. But we evaluated the CYP3A activity by microsomal formation of M17 from cyclosporine A. However, when cyclosporin A was orally administered, the from that in wild-type mice. Thus, we concluded that P-gp plays only a small role in the intestinal absorption of cyclosporin A under physiological conditions [21]. In the present study, after administration of cyclosporin A into the regional intestinal loops, the blood concentrations of cyclosporin A and metabolite M17 were similar in mdr $1 a / 1 b$ knockout mice and wild-type mice, except that the blood concentration of cyclosporin A after administration into the lower intestine was higher in $m d r 1 a / 1 b$ knockout mice than in wild-type mice (Fig. 2a). This may be due to lack of the absorption barrier function of P-gp in mdr1a/1b knockout mice, although the lower intestine is only a minor absorption site of cyclosporin A. After dexamethasone treatment, P-gp significantly affected the bioavailability of cyclosporin A [21], because of strong induction of P-gp in the upper intestine. As shown in Fig. 2b, dexamethasone treatment lowered the blood concentration of M17 after administration of cyclosporin A into the upper intestinal loop of wild-type mice. This suggests that M17 is also a substrate of P-gp. Therefore, there may be complex interactions among intact cyclosporin A, its metabolites, P-gp, and metabolizing enzymes at the absorption sites.

In conclusion, we have confirmed that cyclosporin $\mathrm{A}$ is absorbed predominantly from the upper intestine in mice. CYP3A and P-gp are highly expressed and function predominantly in the upper intestine and the lower intestine, respectively, but are strongly induced by high-dose steroid hormone at the sites where their expression is weak in untreated animals. Therefore, the oral bioavailability of cyclosporin A is primarily controlled by CYP3A in the upper small intestine of mice under physiological conditions, whereas after treatment with inducers, P-gp in the upper intestine also plays a significant role as an absorption barrier to cyclosporin A.

[1] Ohlman S, Lindholm A, Hagglund H, Sawe J, Kahan BD. On the intraindividual variability and chronobiology of cyclosporine pharmacokinetics in renal transplantation. Eur J Clin Pharmacol 1993;44:265-9.

[2] Kahan BD. Therapeutic drug monitoring of cyclosporine: 20 years of progress. Transplant Proc 2004;36:378-91.

[3] Abendroth D. Experience with therapeutic drug monitoring of cyclosporine. Transplant Proc 2004;36:426-9.

[4] Greiner B, Eichelbaum M, Fritz P, Kreichgauer HP, von Richter O, Zundler J, et al. The role of intestinal Pglycoprotein in the interaction of digoxin and rifampin. J Clin Invest 1999;104:147-53.

[5] Nakayama A, Saitoh H, Oda M, Takada M, Aungst BJ. Region-dependent disappearance of vinblastine in rat small intestine and characterization of its P-glycoproteinmediated efflux system. Eur J Pharm Sci 2000;11:317-24.

[6] Di Marco MP, Edwards DJ, Wainer IW, Ducharme MP. The effect of grapefruit juice and seville orange juice on the bioavailability in $m d r 1 a / 1 b$ knockout mice was not different 
pharmacokinetics of dexamethasone tromethorphan: the role of gut CYP3A and P-glycoprotein. Life Sci 2002;71: 1149-60.

[7] Saitoh H, Saikachi Y, Kobayashi M, Yamaguchi M, Oda M, Yuhki Y, et al. Limited interaction between tacrolimus and P-glycoprotein in the rat small intestine. Eur J Pharm Sci 2006;28:34-42.

[8] Zimmerman JJ. Exposure-response relationships and drug interactions of sirolimus. AAPS J 2004;6:e28.

[9] Tamai I, Safa AR. Competitive interaction of cyclosporins with the Vinca alkaloid-binding site of P-glycoprotein in multidrug-resistant cells. J Biol Chem 1990;265:16509-13.

[10] Watkins PB. Drug metabolism by cytochromes P450 in the liver and small bowel. Gastroenterol Clin North Am 1992;21:511-26.

[11] Lown KS, Mayo RR, Leichtman AB, Hsiao HL, Turgeon DK, Schmiedlin-Ren $\mathrm{P}$, et al. Role of intestinal P-glycoprotein (mdr1) in interpatient variation in the oral bioavailability of cyclosporine. Clin Pharmacol Ther 1997;62:248-60.

[12] Watkins PB, Wrighton SA, Schuetz EG, Molowa DT, Guzelian PS. Identification of glucocorticoid-inducible cytochromes P-450 in the intestinal mucosa of rats and man. J Clin Invest 1987;80:1029-36.

[13] de Waziers I, Cugnenc PH, Yang CS, Leroux JP, Beaune PH. Cytochrome P 450 isoenzymes, epoxide hydrolase and glutathione transferases in rat and human hepatic andexamethasone trahepatic tissues. J Pharmacol Exp Ther 1990;253:387-94.

[14] Paine MF, Khalighi M, Fisher JM, Shen DD, Kunze KL, Marsh $\mathrm{CL}$, et al. Characterization of interintestinal and intraintestinal variations in human CYP3A-dependent metabolism. J Pharmacol Exp Ther 1997;283:1552-62.

[15] Hebert MF, Roberts JP, Prueksaritanont T, Benet LZ. Bioavailability of cyclosporine with concomitant rifampin administration is markedly less than predicted by hepatic enzyme induction. Clin Pharmacol Ther 1992;52:453-7.

[16] Wu CY, Benet LZ, Hebert MF, Gupta SK, Rowland M, Gomez DY, et al. Differentiation of absorption and first-pass gut and hepatic metabolism in humans: studies with cyclosporine. Clin Pharmacol Ther 1995;58:492-7.

[17] Yokogawa K, Shimada T, Higashi Y, Itoh Y, Masue T, Ishizaki J, et al. Modulation of mdr1a and CYP3A gene expression in the intestine and liver as possible cause of changes in the cyclosporin A disposition kinetics by dexamethasone amethasone. Biochem Pharmacol 2002;63:777-83.

[18] Shimada T, Terada A, Yokogawa K, Kaneko H, Nomura M, Kaji K, et al. Lowered blood concentration of tacrolimus and its recovery with changes in expression of CYP3A and P-glycoprotein after high-dose steroid therapy. Transplantation 2002;74:1419-24.

[19] Hsiu SL, Hou YC, Wang YH, Tsao CW, Su SF, Chao PD. Quercetin significantly decreased cyclosporin oral bioavailability in pigs and rats. Life Sci 2002;72:227-35.

[20] Konishi H, Sumi M, Shibata N, Takada K, Minouchi T, Yamaji A. Decrease in oral bioavailability of cyclosporin by intravenous pulse of methylprednisolone succinate in rats. J Pharm Pharmacol 2004;56:1259-66.

[21] Jin M, Shimada T, Yokogawa K, Nomura M, Kato Y, Tsuji A, et al. Contributions of intestinal P-glycoprotein and CYP3A to oral bioavailability of cyclosporin A in mice treated with or without dexamethasone amethasone. Int J Pharm 2006;309:81-6.

[22] Bronner F, Yost JH. Saturable and nonsaturable copper and calcium transport in mouse duodenum. Am J Physiol 1985;249:108-12.

[23] Paladino J, Kucharczyk N, Morris AD, Thibault-Naze M, Mahieu JP, Serkiz B, et al. Estimation of blood levels of endothelin and neurokinin receptor antagonists at the rat portal and jugular veins after oral administration as a tool in peptide drug design. Drug Des Discov 1994;12:121-8.

[24] Kamataki T, Kitagawa H. Effects of lyophilization and storage of rat liver microsomes on activity of aniline hydroxylase, contents of cytochrome b5 and cytochrome P450 and aniline-induced P-450 difference spectrum. Jpn J Pharmacol 1974;24:195-203.

[25] Lowry OH, Rosenbrough NJ, Farr AL, Randall RJ. Protein measurement with Folin phenol reagent. J Biol Chem 1951;193:265-75.

[26] Arlotto MP, Trant JM, Estabrook RW. Measurement of steroid hydroxylation reactions by high-performance liquid chromatography as indicator of P450 identity and function. Methods Enzymol 1991;206:454-62.

[27] Khoschsorur G, Semmelrock HJ, Rodl S, Auer T, Petek W, Iberer F, et al. Rapid, sensitive high-performance liquid chromatographic method for the determination of cyclosporin A and its metabolites M1, M17 and M21. J Chromatogr B Biomed Sci Appl 1997;690:367-72.

[28] Croop JM, Raymond M, Haber D, Devault A, Arceci RJ, Gros $\mathrm{P}$, et al. The three mouse multidrug resistance (mdr) genes are expressed in a tissue-specific manner in normal mouse tissues. Mol Cell Biol 1989;9:1346-50.

[29] Seree E, Villard PH, Hever A, Guigal N, Puyoou F, Charvet B, et al. Modulation of MDR1 and CYP3A expression by dexamethasone amethasone: evidence for an inverse regulation in adrenals. Biochem Biophys Res Commun 1998;252:392-5.

[30] Waki Y, Miyamoto K, Kasugai S, Ohya K. Osteoporosis-like changes in Walker carcinoma 256-bearing rats, not accompanied with hypercalcemia or parathyroid hormonerelated protein production. Jpn J Cancer Res 1995;86:470-6.

[31] Laemmli UK. Cleavage of structure proteins during the assembly of the head of bacteriophage T4. Nat Lond 1970;227:680-5.

[32] Guengerich FP, Wang P, Davidson NK. Estimation of isozymes of microsomal cytochrome P-450 in rats, rabbits and humans using immunochemical staining coupled with sodium dodecyl sulfate-polyacrylamide gel electrophoresis. Biochemistry 1982;21:1698-706.

[33] Thorn M, Finnstrom N, Lundgren S, Rane A, Loof L. Cytochromes P450 and MDR1 mRNA expression along the human gastrointestinal tract. Br J Clin Pharmacol 2005;60:54-60.

[34] Yamaguchi H, Yano I, Saito H, Inui K. Pharmacokinetic role of P-glycoprotein in oral bioavailability and intestinal secretion of grepafloxacin in vivo. J Pharmacol Exp Ther 2002;300:1063-9.

[35] Cakaloglu Y, Marinos G, Marsden J, Peters TJ, Williams R, Tredger JM. Localization of cyclosporin A absorption in rat small bowel and the effect of bile. Clin Sci 1993;84:675-9.

[36] Vickers AE, Fisher RL, Brendel K, Guertler J, Dannecker R, Keller B, et al. Sites of biotransformation for the cyclosporin derivative SDZ IMM 125 using human liver and kidney slices and intestine. Drug Metab Dispos 1995;23:327-33.

[37] Brozmanova H, Grundmann M, Safarcik K, Jegorov A. Highperformance liquid chromatographic method for therapeutic drug monitoring of cyclosporine A and its two metabolites in renal transplant patients. J Chromatogr B Biomed Sci 2000;749:93-100.

[38] Schuetz EG, Umbenhauer DR, Yasuda K, Brimer C, Nguyen $\mathrm{L}$, Relling MV, et al. Altered expression of hepatic cytochromes P-450 in mice deficient in one or more mdr1 genes. Mol Pharmacol 2000;57:188-97. 